\title{
An E-Services Success Measurement Framework
}

\author{
Abdel Nasser H. Zaied \\ Vice-dean for Education and Students Affairs, \\ College of Computers and Informatics, \\ Zagazig University, Egypt \\ E-mail: nasserhr@zu.edu.eg, nasserhr@gmail.com
}

\begin{abstract}
The introduction of e-service solutions within the public sector has primarily been concerned with moving away from traditional information monopolies and hierarchies. E-service aims at increasing the convenience and accessibility of government services and information to citizens. Providing services to the public through the Web may lead to faster and more convenient access to government services with fewer errors. It also means that governmental units may realize increased efficiencies, cost reductions, and potentially better customer service. The main objectives of this work are to study and identify the success criteria of e-service delivery and to propose a comprehensive, multidimensional framework of e-services success. To examine the validity of the proposed framework, a sample of 200 e-service users were asked to assess their perspectives towards e-service delivery in some Egyptian organizations. The results showed that the proposed framework is applicable and implementable in the eservices evaluation; it also shows that the proposed framework may assist decision makers and e-service system designers to consider different criteria and measures before committing to a particular choice of e-service or to evaluate any existing e-service system.
\end{abstract}

Index Terms-IS success model, e-services success model, e-services success measurement framework.

\section{Introduction}

Since the late 1990s, governments at all levels had been launched electronic government (eGovernment) projects aimed at providing electronic information and services to citizens and businesses. In recent years, many citizens had been demanded more and better services through the Internet ${ }^{[1]}$. As governments developed systems to deliver these services, there is a need for evaluation efforts that assess the effectiveness of their eservice systems. In 2003, DeLone \& McLean [2] developed an information systems success model; also Croom \& Johnston ${ }^{[3]}$ developed an e-service model to enhance internal customer service through eprocurement. In 2006, Zhang et al. ${ }^{[4]}$ studied factors affecting e-service satisfaction whereas in 2007, Johnson [5] developed framework for pricing government eservices. This work focused on the updated DeLone \&
McLean's ${ }^{[2]}$ information systems success model in the context of e-services and proposed an e-services success measurement framework consists of three phases (design, implementation and results phases). The proposed framework examines how the five dimensions of quality (system quality; information quality; e-service quality; customer satisfaction; and net benefits) influence the success of applying e-services. In addition, this study aims at providing important guidelines when designing and implementing e-services system.

The remainder of this paper is organized as follows. Section 2 presents e-services, whereas, section 3 presents DeLone and McLean information system success model. Section 4 describes the proposed e-service success measurement framework, whereas, section 5 presents the formulation of proposed measurement framework Formulation. In Section 6, we apply this framework and in section 7 we discuss the results. Finally, we conclude with summaries of this work.

\section{E-services}

E-service research had been primarily concerned with the provision and development of service between an organization and its external customers ${ }^{[3]}$. E-service is the integration of business processes, policies, procedures, tools, technologies, and human efforts to facilitate both assisted and unassisted customer services in using the Internet and other networks ${ }^{[4]}$. Government provides services at different levels: for various governments (government-to-government), for private enterprise initiators (government-to-business) and for citizenry access (government-to-citizens). Governmentto-citizens service involves all the communication or transactions between government, at various levels, and citizens. Now governments are developing the next stage of e-government by establishing the electronic service (e-service) infrastructure and organizational capacity for constituents to transact official business online ${ }^{[5]}$.

E-services provide a unique opportunity for businesses to offer new models for service design strategies and new service development. The Internet became a platform for business transactions. Enterprises 
provide e-services via the Internet to generate new revenue or create new efficiencies ${ }^{[6]}$. Rust \& Kannan ${ }^{[7]}$ defined e-service as "the provision of service over electronic networks". Whereas, Wang et al., ${ }^{[8]}$ defined it as "the information and services provided to the public on government web sites". Also, Rowley ${ }^{[9]}$ defined eservices as "deeds, efforts or performances whose delivery is mediated by information technology. Such eservice includes the service element of e-tailing, customer support, and service delivery".

\section{DeLone and McLean Information System Success Model}

Despite the large number of empirical studies in information system (IS) success, what exactly is meant by "IS success" has never been clear. The problem is compounded because success is a multidimensional concept that can be assessed at different levels (such as technical, individual, group, organizational) and using a number of not necessarily complementary criteria such as economic, financial, behavioral and perceptual ${ }^{[10]}$.

\subsection{DeLone and McLean Model Description}

In 1992, DeLone and McLean ${ }^{[1]}$ comprehensively reviewed IS success measures and concluded with a model of interrelationships between six IS success variable categories: 'system quality'; 'information quality'; 'use'; 'user satisfaction'; 'individual impact' and 'organizational impact' as shown in figure 1.

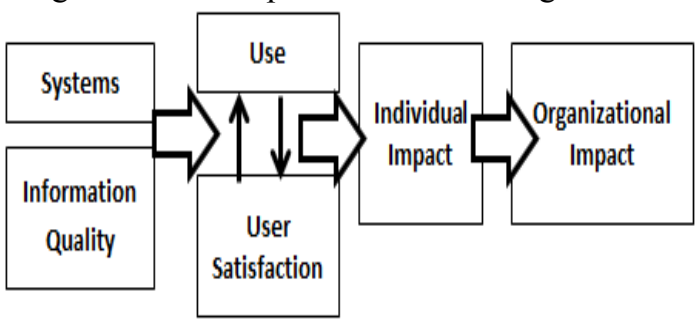

Fig 1: DeLone and McLean’s 1992 Model

Later, DeLone \& McLean ${ }^{[2]}$ introduced an update to their IS success model. Figure 2 shows the main changes concerned quality and service quality. They defined their model dimension as follows:

- Systems quality: measured by adaptability; availability; reliability; response time; and usability

- Information quality: measured by completeness; ease of understanding; personalization; relevance; and security

- Service quality: measured by assurance; empathy; and responsiveness

- Use: measured by nature of use; navigation patterns; number of site visits; and number of transactions executed

- User satisfaction: measured by repeat purchases; repeat visits; and user surveys
- Net benefits: measured by cost savings; expanded markets; incremental additional sales; reduced search costs; and time savings

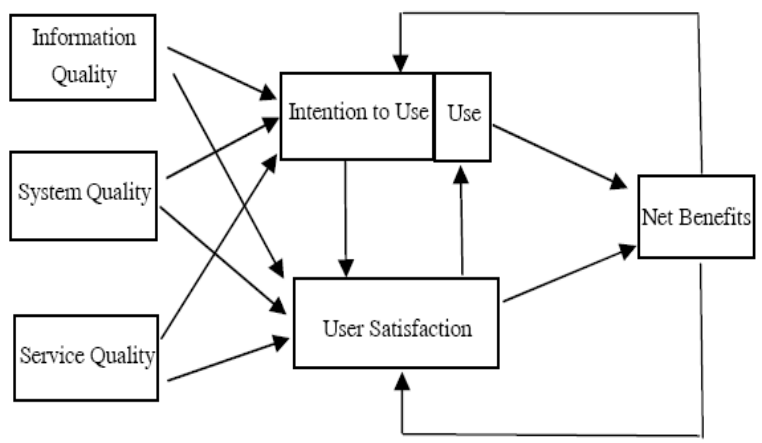

Fig 2: The updated DeLone and McLean's 2003 Model

Many empirical studies supported the updated DeLone and McLean (D\&M) model ${ }^{[1],[12-15]}$.

\section{Dimensions of Proposed e-service Success Measurement Framework}

The increasing investment for the development and provision of e-services by numerous private enterprises and public organizations, which had been resulted in a wide availability of various kinds of e-services in many countries, and at the same time the low level of usage of them in comparison with expectations and the quality problems reported by ${ }^{[16-18]}$ and they did a considerable research in the area of e-service evaluation and quality. In accordance with $\mathrm{D} \& \mathrm{M}^{[2]}$ model, this study proposes a comprehensive, multidimensional framework of eservices systems success. The measures used in this work were adapted primarily from previous researches; the dimensions of proposed e-services success measurement framework are shown in figure 3 . In reality, every study has interpreted and classified information quality system criteria conform to its context, the proposed e-services success measurement framework consists of forty four measures (thirty measures used to assess degree of success in design phase, eight measures used to assess degree of success in implementation phase and six measures used to assess degree of success in results phase) as follows:

\subsection{Design Phase}

\subsubsection{Measures of System Quality}

Ten items were selected to measure system quality, which covered the functionality and desired characteristics of the e-service. These items were selected from the previous studies done by ${ }^{[1],[19-31]}$. The selected system quality measures are: website design; reliability; response time; usability; adaptability; trust; usefulness; availability; maintainability; and navigation. 


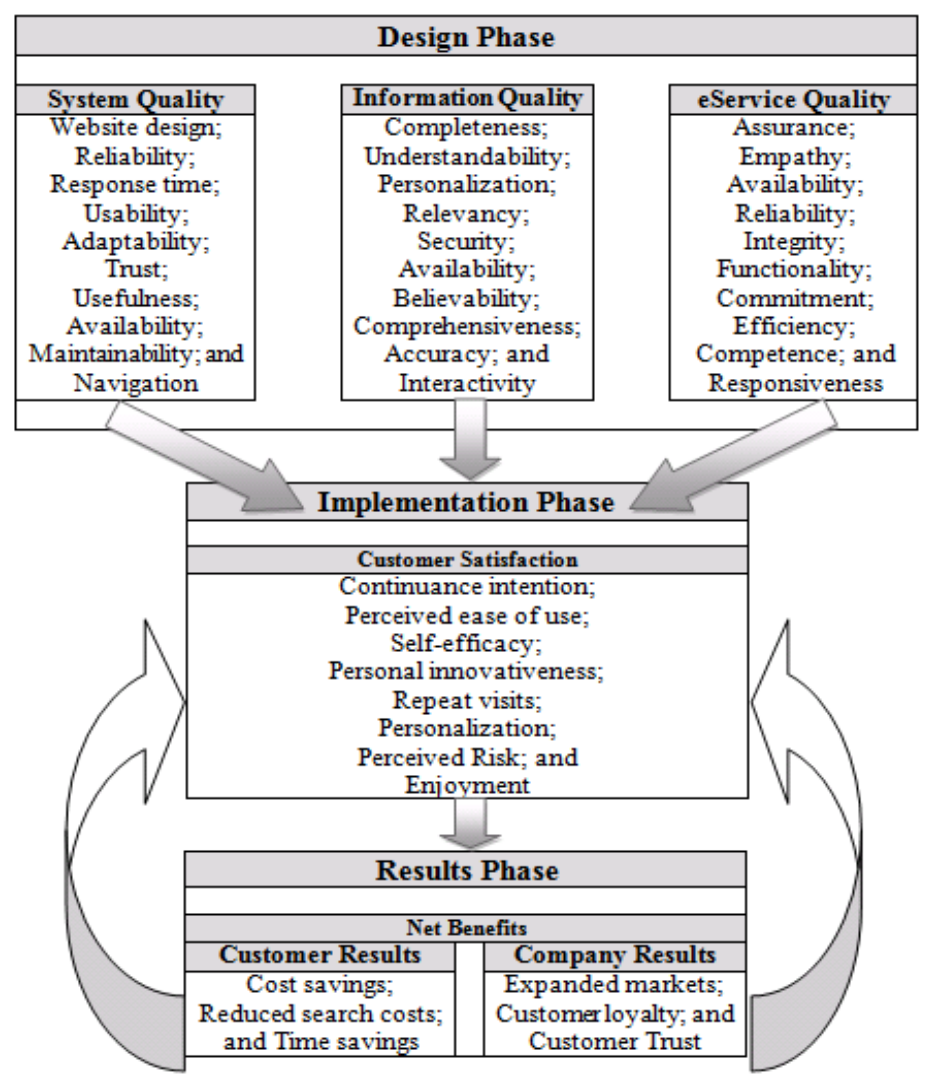

Fig 3: Dimensions of proposed e-services success measurement framework

\subsubsection{Measures of Information Quality}

Ten items were selected to measure information quality, which were measures of the characteristics of information provided by government Web sites. These items were selected from the previous studies done by $[1],[13-14],[20],[27],[30],[32-34]$. The selected information quality measures are: completeness; understandability; personalization; relevancy; security; availability; believability; comprehensiveness; accuracy; and interactivity.

\subsubsection{Measures of e-service Quality}

Ten items were selected to measure e-service quality from the previous studies done by [3],[20],[35-41] The selected e-service quality measures are: assurance; empathy; availability; reliability; integrity; functionality; commitment; efficiency; competence; and responsiveness.

\subsection{Implementation Phase}

\subsubsection{Measures of Customer Satisfaction}

The intent of these measures is to measure customer satisfaction by assessing whether customers like eservice enough to use it again. These measures are relevant only for e-services that are supplied several times. Eight items were selected to measure customer satisfaction from the previous studies done [20],[23],[25$26],[31],[40],[42-46]$

These measures are: continuance intention; perceived ease of use; self-efficacy; personal innovativeness; repeat visits; personalization; perceived risk; and enjoyment.

\subsection{Results Phase}

\subsubsection{Measures of Net Benefits}

E-service is offering a large number of benefits, based on the advantages of using e-service we can classify them in two main categories: customer benefits and company benefits as follows:

- Customer results: cost savings; reduced search costs; and time savings.

- Company results: expanded markets; customer loyalty; and customer trust.

The six measures were selected from the previous studies done by ${ }^{[1],[20],[23],[40],[47-50]}$.

\section{Proposed Measurement Framework Formulation}

The degree of e-service success can be formulated as a function of the degree of satisfactions along the three phases as follows:

- Degree of e-service success $(\mathrm{DS})=$ Degree of satisfactions for the three phase (DSP)

$$
D S=\sum_{i=1}^{3}\left((D S P)_{i}\right) \times \mathrm{I}_{\mathrm{i}}
$$

- Degree of satisfactions for each phase (DSP) = Degree of satisfactions for each dimension in each phase (DSD) 


\section{$(\mathrm{DSP})_{\mathrm{i}}={ }_{n}^{1}\left[\sum_{t=1}^{n}\left((D S D)_{t}\right)\right]$}

- Degree of satisfactions for each dimension in each phase $(D S D)=$ Degree of satisfactions for each measure in each dimension in each phase (DSM)

$$
(\mathrm{DSD})_{\mathrm{j}}=\frac{1}{m}\left[\sum_{k=1}^{m}\left((\boldsymbol{D S M})_{k}\right)_{]} \ldots\right.
$$

The general form of degree of e-service success (DS) can be derived by substituting equations 2 and 3 in equation 1 as follows:

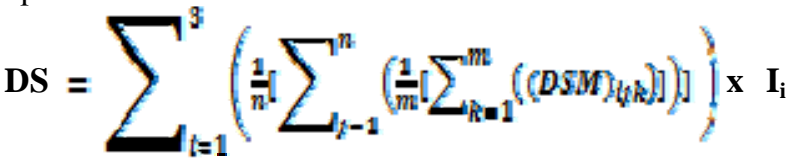

Where:

$\mathbf{I i}=$ degree (percentage) of importance for each phase;

$\mathbf{n}=$ number of dimensions in each phase;

$\mathbf{m}=$ number of measures in each dimension.

\section{Case Study}

To examine the validity of the proposed measurement framework, case study was taken from eservices users with at least one year experiences in eservice applications.

\subsection{Evaluation tool}

In this work, a questionnaire was used as an evaluation tool; it was derived using the suggested measures. Several professors and IS professionals were interviewed to modify the statements and the construction of the questionnaire. They also asked to assign the degree (percentage) of importance for each phase. The degrees of importance are as follows: Design phase $60 \%$; Implementation phase $20 \%$ and Results phase $20 \%$. The final version of the questionnaire consists of one hundred and sixteen statements $(28 ; 28$; 28; 20 \& 12 statements for systems quality; information quality; service quality; user satisfaction and net benefits dimensions). Appendix (A) shows sample of questionnaire statements.

\subsection{Research sample and data collection}

This work used quota sample. Quota sample is a convenience sample in which the size of the sample does not reflect the population as a whole. To assure the participants quick and correct response, the questionnaire copies submitted to managers in ten organizations, two hundred participants were selected as a research sample. Participants' experiences with eservices were used only to select research sample.

The participants were asked to visit three predefined websites offer e-services and indicate the extent of their agreement or disagreement on a fivepoint Likert-type scale (1- completely agree, 2- agree, 3don't know, 4- disagree \& 5 - completely disagree).

To reveal the participants' opinions regarding to the measurement framework dimensions, the evaluation on each dimension were grouped and the degree of satisfactions for each dimension was calculated as shown in Table $1.35 .7 \%$ of the participants completely agree with framework statements and measures, $25.1 \%$ agree; $19.7 \%$ don't know; $10.9 \%$ disagree and $8.6 \%$ completely disagree. A summary for all results are shown in Appendix (B).

\begin{tabular}{|c|c|c|c|c|c|c|}
\hline Phases & Dimensions & Completely agree & Agree & Don't know & Disagree & $\begin{array}{c}\text { Completely } \\
\text { disagree }\end{array}$ \\
\hline \multirow{3}{*}{ Design Phase } & System Quality & 3.62 & 2.63 & 2.01 & 1.03 & 0.71 \\
\hline & Information Quality & 3.63 & 2.54 & 1.99 & 1.05 & 0.79 \\
\hline & e-service Quality & 3.59 & 2.57 & 2.01 & 1.06 & 0.77 \\
\hline Implementation Phase & Customer Satisfaction & 3.53 & 2.34 & 2.13 & 1.01 & 0.99 \\
\hline Results Phase & Net Benefits & 3.58 & 2.62 & 1.78 & 1.22 & 0.8 \\
\hline
\end{tabular}

Table (1): Summary of Results

\section{Results and Analysis}

The aim of the case study was to check the proposed framework validity not to test the predefined websites usability. Pearson correlation was used to examine is there any correlation between the proposed framework components? The results show that the correlation coefficients are more than 0.7 ; it means that there is a strong positive correlation between framework components as shown in tables $2 \& 3$.
Table (2): Correlation Coefficients for design phase

\begin{tabular}{|c|c|c|c|}
\hline Dimensions & $\begin{array}{c}\text { System } \\
\text { Quality }\end{array}$ & $\begin{array}{c}\text { Information } \\
\text { Quality }\end{array}$ & $\begin{array}{c}\text { e-service } \\
\text { Quality }\end{array}$ \\
\hline System Quality & & 0.998997 & 0.999773 \\
\hline $\begin{array}{c}\text { Information } \\
\text { Quality }\end{array}$ & 0.998997 & & 0.999697 \\
\hline $\begin{array}{c}\text { e-service } \\
\text { Quality }\end{array}$ & 0.999773 & 0.999697 & \\
\hline
\end{tabular}


Table (3): Correlation Coefficients for design phase

\begin{tabular}{|c|c|c|c|}
\hline Phases & $\begin{array}{c}\text { Design } \\
\text { phase }\end{array}$ & $\begin{array}{c}\text { Implementation } \\
\text { phase }\end{array}$ & $\begin{array}{c}\text { Results } \\
\text { phase }\end{array}$ \\
\hline Design phase & & 0.99005 & 0.962293 \\
\hline $\begin{array}{c}\text { Implementation } \\
\text { phase }\end{array}$ & 0.99005 & & 0.930672 \\
\hline Results phase & 0.962293 & 0.930672 & \\
\hline
\end{tabular}

The proposed framework had been used to assess the degree of e-services success from the participants' perspective using equations from (1) to (3) or the general form in equation (4) as follows:

$\begin{array}{lc}\mathbf{D S D}_{\mathbf{1}} \text { (System quality dimension) } & =2.50 \\ \mathbf{D S D}_{\mathbf{2}} \text { (Information quality dimension) } & =2.48 \\ \mathbf{D S D}_{\mathbf{3}} \text { (Service quality dimension) } & =2.48 \\ \mathbf{D S D}_{\mathbf{4}} \text { (Customer satisfaction dimension) } & =2.43 \\ \mathbf{D S D}_{\mathbf{5}} \text { (Net benefits dimension) } & =2.74\end{array}$

Degree of satisfactions for each phase (DSP)

$\mathbf{D S P}_{1}$ (Design phase) $\quad=2.48(\mathbf{4 9 . 6} \%)$

$\mathbf{D S P}_{2}$ (Implementation phase) $=2.48(\mathbf{4 9 . 6} \%)$

$\mathbf{D S P}_{3}$ (Results phase) $\quad=2.74(54.8 \%)$

The general degree of e-service success (DS)

$$
\begin{aligned}
\text { DS } & =(2.48 \times 0.6)+(2.48 \times 0.2)+(2.74 \times 0.2) \\
& =2.532(51 \%)
\end{aligned}
$$

The results show that the degree of e-service success depends on the degree of customer satisfactions. It also show that customers satisfied on design and implementation phases by $49.6 \%$ and in results phase by $54.8 \%$. Total satisfactions of using the tested websites (e-service success) is $51 \%$, it means that there is an opportunity to improve website usages to increase customer satisfactions for e-service.

\section{Conclusion}

This work proposes a framework for evaluating eservice application success. The work modified D\&M 2003 by canceling one dimension (intention to use) and adding many measures to assess the other five dimensions. It doesn't focus on single dimensions of IS success as ${ }^{[18],[51-52]}$. Instead, it describes the probability of success during e-service life cycle (from design to results). The case study showed that the proposed framework is applicable and implementable in the eservices evaluation process, it also showed that the proposed framework may assist decision makers and eservice system designers to consider different criteria and measures before committing to a particular choice of e-service or to evaluate any existing e-service system. The findings obtained from the case study show several conclusions. First, the design phase has a strong and significant influence on other phases, and as consequence, the overall degree of success of e-service. Thus, e-service system designers should make full use of the proposed measures to increase user satisfaction and behavioral intention to use e-service. Second, because e-service lacks physical contact, e-service system designers should focus on methods that attract and encourage participations in using e-service. They also should actively seek methods of improving system and service quality, since these factors significantly affect user satisfaction. Finally, the proposed framework of e-services systems success derived in this work can be used as a reference for e-service planning and improvements. Future studies can validate these results by replicating this study with specific type of e-service (e-procurement, e-shopping, e-banking, etc...) and consequently the degree of importance for each type. Also, it is required to increase sample size to avoid any participants' biasness and be able to generalize the results.

\section{References}

[1] Wang Y., \& Liao Y., "Assessing eGovernment systems success: A validation of the DeLone and McLean model of information systems success", Government Information Quarterly, 2008, 25: 717-733. [2] DeLone W., \& McLean E., "The DeLone and McLean model of information systems success: A tenyear update", Journal of Management Information Systems, 2003, 19(4): 9-30.

[3] Croom S., \& Johnston R., "E-service: enhancing internal customer service through e-procurement", International Journal of Service Industry Management, 2003, 14(5): 539-555.

[4] Zhang X., Prybutok V., \& Huang A., “An empirical study of factors affecting e-service satisfaction", Human Systems Management, 2006, 25(4): 279-291.

[5] Johnson C., "A framework for pricing government e-services", Electronic Commerce Research and Applications, 2007, 6: 484-489.

[6] Liu D., Shen M., \& Liao C., "Designing a composite e-service platform with recommendation function", Computer Standards \& Interfaces, 2003, 25: 103-117.

[7] Rust R., \& Kannan P., "E-service: A new paradigm for business in the electronic environment", Communication of the ACM, 2003, 46(6): 37-42.

[8] Wang L., Bretschneider S., \& Gant J., "Evaluating Web-based e government services with a citizencentric approach", Proceedings of the $38^{\text {th }}$ Hawaii International Conference on System Sciences, 2005: $129 b-139 b$.

[9] Rowley J., "An analysis of the e-service literature: towards a research agenda", Internet Research, 2006, 16(3): 339-359.

[10] Molla A., \& Licker P., "E-commerce systems success: An attempt to extend and re-specify The Delone and Maclean model of IS success", Journal of Electronic Commerce Research, 2001, 2(4): 131-141. [11]DeLone W., \& McLean E., "Information systems success: The quest for the dependent variable", Information Systems Research, 1992, 3(1): 60-95. 
[12] Iivari J., "An Empirical Test of the DeLoneMcLean Model of Information System Success", The Data Base for Advances in Information Systems, 2005, 36(2): 8-27.

[13] Jang C., "Measuring Electronic Government Procurement Success and Testing for the Moderating Effect of Computer Self-efficacy", International Journal of Digital Content Technology and its Applications, 2010, 4(3): 224-232.

[14]Lin H., "Measuring Online Learning Systems Success: Applying the Updated DeLone and McLean Model", Cyberpsychology and Behavior, 2007, 10(6): 817-820.

[15] Wu J., \& Wang Y., "Measuring KMS success: A respecification of the DeLone and McLean's model", Information \& Management, 2006, 43: 728-739.

[16] European Commission, "Preparing Europe's Digital Future", Mid-Term Review, COM/2008/0199.

[17] Parasuraman A., Zeithaml V. \& Malhotra, A., "ES-QUAL:a multiple-item scale for assessing electronic service quality", Journal of Service Research, 2005, 7(3): 213-233.

[18] Šumak B., Polančič G., \& Heričko M., "Towards an e-service knowledge system for improving the quality and adoption of e-services. $22^{\text {nd }}$ Bled eConference eEnablement: Facilitating an Open, Effective and Representative eSociety, Bled, Slovenia, 2009: 638-653.

[19] Cristoal E., Flavian C., \& Guinaliu M., "Perceived e-service quality: Measurement validity and effects on consumer satisfaction and web site loyalty", Managing Service Quality, vol. 17, no. 3, pp. 317-340, 2007.

[20]DeLone W., \& McLean E., "Measuring eCommerce Success: Applying the DeLone \& McLean Information Systems Success Model", International Journal of Electronic Commerce, 2004, 9(1): 31-47.

[21]Fassnacht M., \& Koese I., "Quality of electronic services: Conceptualizing and testing a hierarchical model, Journal of Service Research, 2006, 9(1): 19-31. [22] Field J., Heim G., \& Sinha K., "Managing quality in the e-service system: Development and application of a process model", Production and Operations Management, 2004, 13(4): 291-306.

[23] Flavian C., Guinalı'u M., \& Gurrea R., "The role played by perceived usability, satisfaction and consumer trust on website loyalty", Information \& Management, vol. 43, pp. 1-14, 2006.

[24] Gounaris S., Dimitriadis S., \& Stathakopoulos V., "Antecedents of perceived quality in the context of Internet retail stores", Journal of Marketing Management, 2005, 21(7): 669-682.

[25] Grigoroudis E., Litos C., Moustakis V., Politis Y., and Tsironis L., "The assessment of user-perceived web quality: Application of a satisfaction benchmarking approach", European Journal of Operational Research, vol. 187, pp. 1346-1357, 2008.

[26] Liao C., Chen J., \& Yen D., "Theory of planning behavior (TPB) and customer satisfaction in the continued use of e-service: An integrated model", Computers in Human Behavior, 2007, 23: 2804-2822.
[27] Naumann F., \& Rolker C., "Assessment methods for information quality criteria", Proceedings of $5^{\text {th }}$ International Conference on Information Quality, 2000: $148-162$.

[28] Santos J., "E-Service quality: a model of virtual service quality dimensions", Managing Service Quality, 2003, 13(3): 233-247.

[29] Sohn C., and Tadisina S., "Development of eservice quality measure for the internet-based financial institutions", Total Quality Management \& Business Excellence, 2008, 19(9): 903-918.

[30] Swaid S., \& Wigand R., "Key Dimensions of Ecommerce Service Quality and Its Relationships to Satisfaction and Loyalty", $20^{\text {th }}$ Bled eConference eMergence: Merging and Emerging Technologies, Processes, and Institutions, Bled, Slovenia, 2007: 414428.

[31]Udo G., Bagchi K., \& Kirs P., “An assessment of customers' e-service quality perception, satisfaction and intention", International Journal of Information Management, 2010, 30: 481-492.

[32] Eppler M., \& Muenzenmayer P., "Measuring information quality in the web context: A survey of state-of-the-art instruments and an application methodology", Proceedings of $7^{\text {th }}$ International Conference on Information Quality, 2002: 187-196.

[33] Kargar M., Ramli A., Ibrahim H., \& Azimzadeh F., "Formulating Priory of Information Quality Criteria on the Blog", World Applied Sciences Journal, 2008, 4(4): 586-593.

[34] Knight S., and Burn J., "Developing a Framework for Assessing Information Quality on the World Wide Web”, Informing Science Journal, 2005, 8: 159-172.

[35] Adam F., "Investigating the non-linear effects of e-service quality dimensions on customer satisfaction, Journal of Retailing and Consumer Services, 2011, 18 : 27-37.

[36] Collier J., \& Bienstock C., "Measuring Service Quality in E-Retailing", Journal of Service Research, 2006, 8(3): 260-275.

[37] Connolly R., \& Bannister F., "eTax Filing \& Service Quality: The Case of the Revenue Online Service", Proceedings of World Academy of Science: Engineering and Technology, 2008, 48: 313-317.

[38] Lee F., \& Wu W., "Moderating effects of technology acceptance perspectives on e-service quality formation: Evidence from airline websites in Taiwan", Expert Systems with Applications, 2011, 38: 7766-7773.

[39] Madu C. \& Madu A., "Dimensions of equality", International Journal of Quality \& Reliability Management, 2002, 19(3): 246-259.

[40] Walsh G., Hennig-Thurau T., Sassenberg K., \& Bornemann D., "Does relationship quality matter in eservices? A comparison of online and offline retailing", Journal of Retailing and Consumer Services, 2010, 17: 130-142.

[41] Yang Z., \& Fang X., "Online service quality dimensions and their relationships with satisfaction; A content analysis of customer reviews of securities 
brokerage services", International Journal of Service Industry Management, 2004, 15(3): 302-326.

[42] Cyr D., Hassanein K., Head M., \& Ivanov A., "The role of social presence in establishing loyalty in e-Service environments", Interacting with Computers, 2007, 19: 43-56.

[43] Heim G., \& Field J., "Process drivers of e-service quality: Analysis of data from an online rating site", Journal of Operations Management, 2007, 25: 962984.

[44]Hung S., Chang C., \& Yu T., "Determinants of user acceptance of the e-Government services: The case of online tax filing and payment system", Government Information Quarterly, 2006, 23: 97-122. [45] Udo G., Bagchi K., \& Kirs P., "Assessing Web Service Quality Dimensions: The E- SERVPERF APPROACH", Issues in Information Systems, 2008, 9(2): 313-322.

[46]Zaied A., Khairalla F., "Risk assessment for implementing e-services in some ministries in the State of Kuwait", Arab Gulf Journal of Scientific Research, 2007, 25(3): 138-146.

[47] Boyer K., Hallowell R. \& Roth A., "E-services: operating strategy - a case study and a method for analyzing operational benefits", Journal of Operations Management, 2002, 20: 175-188.

[48] Kaplan S., Nieschwietz R., "A Web assurance services model of trust for B2C e-commerce", International Journal of Accounting Information Systems, 2003, 4: 95-114.

[49] Seth A., Momaya K., \& Gupta H., "E-Service Delivery in Cellular Mobile Communication: Some
Challenges and Issues", Global Journal of e-Business and Knowledge Management, 2005, 2(2): 30-42.

[50] Shun C., \& Yunjie X., "Effects of outcome, process and shopping enjoyment on online consumer behavior", Electronic Commerce Research and Applications, 2006, 5: 272-281.

[51] Magoutas B., Schmidt K., Mentzas G., \& Stojanovic L., "An adaptive e-questionnaire for measuring user perceived portal quality", International Journal of Human-Computer Studies, 2010, 68: 729745.

[52] Petter S., DeLone W., \& McLean E., "Measuring information systems success: models, dimensions, measures, and interrelationships", European Journal of Information Systems, 2008, 17: 236-263.

Abdel Nasser H. Zaied is a Vice-dean for education and students affairs, College of Computers and Informatics, Zagazig University, Egypt. He previously worked as an associate professor of Industrial Engineering, Zagazig University Egypt; an assistant professor of Technology Management, Arabian Gulf University, Bahrain; and as visiting professor at Oakland University, USA. He supervised $8 \mathrm{PhD}$. thesis and $38 \mathrm{MSc}$. thesis, and examined $33 \mathrm{MSc}$ thesis. He published fifteen research papers in International and Regional Journals and 22 research papers in International and National conferences. His areas of research are: Systems Analysis and Design; Information Security; Knowledge Management; Quality Management Systems and project Management.

Appendix (A): Sample of Questionnaire statements

\begin{tabular}{|c|c|c|c|c|c|}
\hline \multirow{2}{*}{$\begin{array}{l}\text { Statement } \\
\text { Dimension: Measures for system quality }\end{array}$} & \multicolumn{5}{|c|}{ Agreements } \\
\hline & 1 & 2 & 3 & 4 & 5 \\
\hline \multicolumn{6}{|l|}{ In the e-service system website everything is easy to understand. } \\
\hline \multicolumn{6}{|l|}{ The e-service system website is simple to use, even when using it for the first time. } \\
\hline \multicolumn{6}{|l|}{ It is easy to find the information I need from the e-service system website. } \\
\hline \multicolumn{6}{|l|}{ The structure and contents of the e-service system website are easy to understand. } \\
\hline Dimension: Measures for information quality & 1 & 2 & 3 & 4 & 5 \\
\hline \multicolumn{6}{|l|}{ The output information of the e-service website is complete and secure. } \\
\hline \multicolumn{6}{|l|}{ Information contains necessary topics to complete related task. } \\
\hline \multicolumn{6}{|l|}{ The e-service website provides information precisely according to my need. } \\
\hline \multicolumn{6}{|l|}{ The output information of the e-service website is easy to understand. } \\
\hline Dimension: Measures for e-service quality & 1 & 2 & 3 & 4 & 5 \\
\hline \multicolumn{6}{|l|}{ Security and privacy policies are accessible. } \\
\hline \multicolumn{6}{|l|}{ The website contains company details. } \\
\hline \multirow{2}{*}{\multicolumn{6}{|c|}{$\begin{array}{l}\text { The website's retailer is widely known for having a good reputation. } \\
\text { The technical functions of e-service website are secured. }\end{array}$}} \\
\hline & & & & & \\
\hline Dimension: Measures for customer satisfaction & 1 & 2 & 3 & 4 & 5 \\
\hline \multicolumn{6}{|l|}{ I intend to continue using e-service rather than discontinue it use. } \\
\hline \multicolumn{6}{|l|}{ I recommend e-services website to others. } \\
\hline \multicolumn{6}{|l|}{ I find the e-services website to be flexible to interact with. } \\
\hline \multicolumn{6}{|l|}{ It is easy for me to become skillful at using e-services website. } \\
\hline Dimension: Measures for Net benefits & 1 & 2 & 3 & 4 & 5 \\
\hline \multicolumn{6}{|l|}{ Reduces overhead costs such as benefits administration. } \\
\hline \multicolumn{6}{|l|}{ Reduces operation time. } \\
\hline \multicolumn{6}{|l|}{ Allows searches of large volumes of different products and services. } \\
\hline Customers can quickly find answers to their most frequently asked questions on e-service website. & & & & & \\
\hline
\end{tabular}


Appendix (B): Results

\begin{tabular}{|c|c|c|c|c|c|c|c|c|c|}
\hline \multicolumn{3}{|c|}{$\begin{array}{c}\% \text { of } \\
\text { importance }\end{array}$} & Measure & $\begin{array}{c}\text { Completely } \\
\text { agree }\end{array}$ & Agree & Don't know & Disagree & $\begin{array}{c}\text { Completely } \\
\text { disagree }\end{array}$ & $\begin{array}{c}\text { Net } \\
\text { results }\end{array}$ \\
\hline \multirow{30}{*}{ 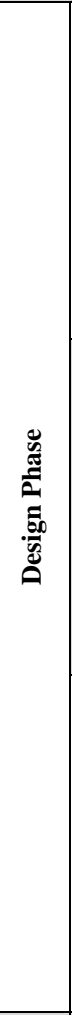 } & \multirow{10}{*}{ 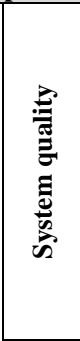 } & \multirow{10}{*}{$\begin{array}{l}\text { o } \\
\text { ᄅे }\end{array}$} & Website design & 3.9 & 2.2 & 2.1 & 1.0 & 0.8 & 2.49 \\
\hline & & & Navigation & 3.3 & 3.0 & 2.0 & 1.0 & 0.7 & 2.48 \\
\hline & & & Trust & 4.0 & 2.2 & 2.0 & 1.1 & 0.7 & 2.51 \\
\hline & & & Usability & 3.3 & 3.0 & 2.0 & 1.0 & 0.7 & 2.48 \\
\hline & & & Reliability & 3.5 & 2.8 & 2.0 & 1.0 & 0.7 & 2.49 \\
\hline & & & Response time & 3.7 & 2.7 & 1.9 & 1.0 & 0.7 & 2.51 \\
\hline & & & Availability & 3.0 & 3.0 & 2.0 & 1.0 & 1.0 & 2.40 \\
\hline & & & Adaptability & 4.3 & 2.2 & 2.0 & 1.2 & 0.3 & 2.60 \\
\hline & & & Usefulness & 3.2 & 3.0 & 2.0 & 1.0 & 0.8 & 2.45 \\
\hline & & & Maintainability & 4.0 & 2.2 & 2.1 & 1.0 & 0.7 & 2.52 \\
\hline & & \multirow{10}{*}{$\begin{array}{l}\text { d̊ } \\
\text { คे }\end{array}$} & Completeness & 3.9 & 2.2 & 2.0 & 1.1 & 0.8 & 2.49 \\
\hline & & & Understandability & 3.9 & 2.2 & 2.0 & 1.0 & 0.9 & 2.48 \\
\hline & & & Personalization & 3.3 & 3.0 & 2.0 & 1.0 & 0.7 & 2.48 \\
\hline & & & Relevancy & 4.0 & 2.1 & 2.0 & 1.2 & 0.7 & 2.50 \\
\hline & & & Security & 3.5 & 2.8 & 2.0 & 1.0 & 0.7 & 2.49 \\
\hline & & & Availability & 3.4 & 2.9 & 1.9 & 1.1 & 0.7 & 2.48 \\
\hline & & & Believability & 3.7 & 2.2 & 2.0 & 1.1 & 1.0 & 2.43 \\
\hline & & & Comprehensiveness & 3.3 & 3.0 & 2.0 & 1.0 & 0.7 & 2.48 \\
\hline & & & Accuracy & 3.3 & 3.0 & 2.0 & 1.0 & 0.7 & 2.48 \\
\hline & & & Interactivity & 4.0 & 2.0 & 2.0 & 1.0 & 1.0 & 2.47 \\
\hline & \multirow{10}{*}{ 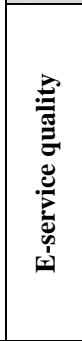 } & \multirow{10}{*}{$\begin{array}{l}\text { d̊ } \\
\text { ㄱ }\end{array}$} & Assurance & 4.0 & 2.2 & 2.1 & 1.0 & 0.7 & 2.52 \\
\hline & & & Empathy & 3.3 & 3.0 & 2.0 & 1.0 & 0.7 & 2.48 \\
\hline & & & Availability & 3.3 & 3.0 & 2.0 & 1.0 & 0.7 & 2.48 \\
\hline & & & Reliability & 3.7 & 2.1 & 2.0 & 1.2 & 1.0 & 2.42 \\
\hline & & & Integrity & 3.2 & 3.0 & 2.0 & 1.0 & 0.8 & 2.45 \\
\hline & & & Functionality & 3.7 & 2.3 & 2.0 & 1.2 & 0.8 & 2.46 \\
\hline & & & Commitment & 3.3 & 3.0 & 2.0 & 1.0 & 0.7 & 2.48 \\
\hline & & & Efficiency & 4.0 & 2.1 & 2.0 & 1.1 & 0.8 & 2.49 \\
\hline & & & Competence & 3.4 & 2.8 & 2.0 & 1.0 & 0.8 & 2.47 \\
\hline & & & Responsiveness & 4.0 & 2.2 & 2.0 & 1.1 & 0.7 & 2.51 \\
\hline \multirow{8}{*}{ 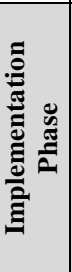 } & \multirow{8}{*}{ } & \multirow{8}{*}{$\begin{array}{l}\text { de } \\
\text { 尺े }\end{array}$} & Continuance intention & 3.3 & 2.8 & 2.0 & 1.0 & 0.9 & 2.44 \\
\hline & & & Perceived ease of use & 4.0 & 2.0 & 2.0 & 1.0 & 1.0 & 2.47 \\
\hline & & & Self-efficacy & 3.6 & 2.2 & 2.1 & 1.1 & 1.0 & 2.42 \\
\hline & & & Personal innovativeness & 3.0 & 3.0 & 2.0 & 1.0 & 1.0 & 2.40 \\
\hline & & & Repeat visits & 4.0 & 2.0 & 2.0 & 1.0 & 1.0 & 2.47 \\
\hline & & & Personalization & 3.0 & 2.0 & 3.0 & 1.0 & 1.0 & 2.33 \\
\hline & & & Perceived Risk & 3.3 & 2.7 & 2.0 & 1.0 & 1.0 & 2.42 \\
\hline & & & Enjoyment & 4.0 & 2.0 & 2.0 & 1.0 & 1.0 & 2.47 \\
\hline
\end{tabular}

\begin{tabular}{|c|c|c|c|c|c|c|c|c|c|}
\hline \multirow{8}{*}{ 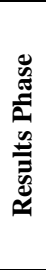 } & \multirow{8}{*}{ 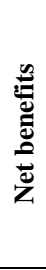 } & \multirow{8}{*}{$\begin{array}{l}\text { d̊ } \\
\text { จे }\end{array}$} & \multicolumn{7}{|c|}{ Customer Results: } \\
\hline & & & Cost savings & 3.0 & 4.0 & 2.0 & 2.0 & 2.0 & 2.87 \\
\hline & & & Reduced search costs & 4.5 & 2.0 & 2.0 & 1.0 & 1.0 & 2.63 \\
\hline & & & Time savings & 3.5 & 4.0 & 2.0 & 2.0 & 2.0 & 3.03 \\
\hline & & & \multicolumn{7}{|c|}{ Company Results: } \\
\hline & & & Expanded markets & 3.0 & 3.0 & 2.0 & 1.0 & 1.0 & 2.40 \\
\hline & & & Customer loyalty & 3.5 & 3.0 & 2.0 & 2.0 & 2.0 & 2.77 \\
\hline & & & Customer Trust & 4.0 & 3.0 & 2.0 & 1.0 & 1.0 & 2.73 \\
\hline
\end{tabular}

